\title{
Translational models of 3-D organoids and cancer stem cells in gastric cancer research
}

\author{
Kenly Wuputra ${ }^{1,2,3}$, Chia-Chen $\mathrm{Ku}^{1,2,3}$, Kohsuke Kato $^{4}$, Deng-Chyang Wu $\mathrm{W}^{2,3,5}$, Shigeo Saito ${ }^{6,7^{*}}$ and \\ Kazunari K. Yokoyama ${ }^{1,2,3,6^{*}}$ (D)
}

\begin{abstract}
It is postulated as a general concept of cancer stem cells (CSCs) that they can produce cancer cells overtly and repopulate cancer progenitor cells indefinitely. The CSC niche is part of a specialized cancer microenvironment that is important to keep the phenotypes of CSCS. Stem cell- and induced pluripotent stem cell (iPSC)-derived organoids with genetic manipulation are beneficial to the investigation of the regulation of the microenvironment of CSCs. It would be useful to assess the efficiency of the cancer microenvironment on initiation and progression of cancers. To identify CSCs in cancer tissues, normal cell organoids and gastric cancer organoids from the cancerous areas, as well as iPSCs, were established several years ago. However, many questions remain about the extent to which these cultures recapitulate the development of the gastrointestinal tract and the mechanism of Helicobacter pylori-induced cancer progression. To clarify the fidelity of human organoid models, we have noted several key issues for the cultivation of, and differences between, normal and cancerous organoids. We developed precise culture conditions for gastric organoids in vitro to improve the accuracy of the generation of organoid models for therapeutic and medical applications. In addition, the current knowledge on gastrointestinal CSC research, including the topic of CSC markers, cancer cell reprogramming, and application to target cancer cell plasticity through niches, should be reinforced. We discuss the progression of cancers derived from human gastric organoids and the identification of CSCs.
\end{abstract}

Keywords: Cancer microenvironment, Cancer stem cells, Human gastric organoids, Gastric cancer, Translational research, Tumor suppressor genes, Patient-specific organoid library

\section{Introduction}

The human stomach is divided into two major regions, i.e., the corpus/fundus and the antrum [1]. The epithelium layer is formed into the fundus gland, consisting of endocrine cells, tuft cells, stem cells, parietal cells (with acid-secretion ability), mucus-producing cells, and chief cells (with pepsinogen-secretion ability) in the corpus [2]. The antrum gland contains endocrine cells, mucus cells included gastrin-producing cells, and tuft cells, but

\footnotetext{
*Correspondence: saict1@maple.ocn.ne.jp; kazu@kmu.edu.tw

${ }^{1}$ Graduate Institute of Medicine, Kaohsiung Medical University, Kaohsiung 80708, Taiwan

${ }^{6}$ Waseda Research Institute of Science and Engineering, Waseda University, Tokyo 169-0051, Japan

Full list of author information is available at the end of the article
}

comprises chief cells. The leucine-rich repeat-containing receptor $(\mathrm{LGR} 5)^{+}$stem cells generate to most cell types in the antrum. The human fundic and antral glands are also organized into three basic regions: the base area, medial isthmus, and surface pit area. Undifferentiated stem cells produce the isthmus. Chief, endocrine, and parietal cells are present in the base area of fundic glands, whereas endocrine, LGR $5^{+}$stem cells, the parietal and chief cells, are found in the base of antral glands. Tuft cells also reside on both glands. The stomach is mainly composed of these gastric epithelial and mesenchymal tissues. Thus, the understanding of the functional development of the gastric epithelium and mesenchymal tissues is critical to elucidate the composition of the stomach. original author(s) and the source, provide a link to the Creative Commons licence, and indicate if changes were made. The images or other third party material in this article are included in the article's Creative Commons licence, unless indicated otherwise in a credit line to the material. If material is not included in the article's Creative Commons licence and your intended use is not permitted by statutory regulation or exceeds the permitted use, you will need to obtain permission directly from the copyright holder. To view a copy of this licence, visit http://creativecommons.org/licenses/by/4.0/. The Creative Commons Public Domain Dedication waiver (http://creativeco mmons.org/publicdomain/zero/1.0/) applies to the data made available in this article, unless otherwise stated in a credit line to the data. 
Recent studies have suggested that different populations of gastric stem cells exist in different parts of the stomach and develop into distinct stem cell populations during stomach development. Cells expressing the most prominent stem cell markers, such as LGR5 and cholecystokinin 2 receptor $\left(\mathrm{CCK} 2 \mathrm{R}^{+}\left[\mathrm{Numb}^{+}, \mathrm{Dlll}^{\text {high }}\right]\right)$, axin 2 (AXIN2), and aquaporin 5 (AQP5), are present in the antrum region. Cells expressing trefoil factor 2 (TFF2) mRNA, and muscle TWIST1 (MIST1) cells and mature chief cells expressing tumor necrosis factor receptor superfamily member 19 (TROY) are present in the corpus region. Furthermore, cells with SOX2, Runx enhancer 1 (eR1), leucine-rich repeats and immunoglobulin-like domains protein 1 (LRIG1), and B cell-specific Moloney murine leukemia virus integration site 1 (BMI1) are present in both the antrum and corpus [3]. The gastric corpus stem cells comprise the following two different stem cell populations: isthmus and base stem cells in the base region $\left(\mathrm{TROY}^{+}\right.$or LGR5 ${ }^{+}$cells) [4] (Figs. 1 and 2 , Table 1). The epithelia of gastric corpus glands in mice are formed by two different stem cells: the proliferating stem cell population in the isthmus area (characterized by Stathmin 1 [STMN 1] and Ki67) and the quiescent population in the base area characterized by specific expression of TROY or LGR5 (Fig. 2) [4]. The stomach stem cells are localized in three different regions. The marker molecules of these stem cells have been reported elsewhere (Fig. 1) [3].

Gastric organoids from fundic, isthmus, and antral origins contain the glandular epitheliums and the mesenchyme layer [5]. The epithelium includes all types of mucus cells, endocrine cells, and chief cells. The fundic organoids include parietal cells expressed proton-pump and can release acid by histamine-response. However, human gastric organoids (HGOs) are not completely equal to adult stomach tissue. For example, HGOs seem to be fetal, i.e., the mesenchyme is not composed in smooth muscle in vitro. Moreover, they do not include vasculature or an enteric nervous system (ENS) [6]. These problems will be solved in the latter part.

Stem-cell-related pluripotency genes, such as OCT4, SOX2, KLF4, MYC, LIN28, and NANOG, are expressed in various types of cancer cells. For instance, OCT4, $S O X 2$, and NANOG (OSN) are upregulated in bladder, breast, colorectal, prostate, and renal carcinogenic cells under the conditions of cultivation of embryonic stem (ES) cells and iPSCs [7]. Pluripotency-inducing transcriptional pathways were found in the aggressive cancers and showed strong resistance to clinical treatments, leading to poor survival. The similarities between cancer formation (tumorigenesis or carcinogenesis) and the iPSCinducing reprogramming process are suggested to be driven by overlapping molecular signaling pathways [8].
The risk of tumorigenesis is happened by some mutations of oncogenes and/or tumor suppressor genes during the transformation of stem cells into cancers with niche cells [9].

\section{Candidate genes related to human gastric cancer}

Recently, RNA sequencing of human gastric adenocarcinoma (GAC) and human gastric adenoma yielded The Cancer Genome Atlas database (http://www.gdc.cancer. gov), and the gastric cancer mRNA expression-based stemness index (mRNAsi) was also reported [10-12] (Table 2). mRNAsi was enhanced in gastric cancer tissues compared with normal gastric tissues $(P<0.0001)$. The following 16 genes were identified as the key genes in gastric cancer: budding uninhibited by benzimidazoles 1 (BUB1), budding uninhibited by benzimidazoles 1 homolog beta $(B U B 1 B)$, non-SMC condensin I complex subunit $\mathrm{H}(N C A P H)$, kinesin family member 14 (KIF14), Rac GTPase-activating protein 1 (RACGAP1), DNA repair and recombination protein RAD54-like (RAD54L), TPX2 microtubule nucleation factor (TPX2), KIF15, KIF18B, centromere protein F (CENPF), dual specificity protein kinase (TTK), KIF4A, shugoshin-like $(S G O L)$, Polo-like kinase 4 (PLK4), X-ray repair cross complementing 2 (XRCC2), and chromosome 1 open reading frame 12 (C1orf12). These genes are related to the spindle cell components, sister chromatid segregation, motor activity, cell-cycle, and homologous recombination. The prognosis of patients with gastric cancer is related to the expression of RAD54L, TPX2, and XRCC2 genes [10]. The protein-protein interaction network and the Cane Genome Atlas database showed that the expression of fibronectin 1 (FN1), serpin family E member 1 (SERPINE1), secreted protein acidic and rich in cysteine (SPARC) are related to the poor prognosis of GACs [11]. Identification of these target genes aids in understanding the mechanism of gastric cancer development and enables drug developments to prevent gastric cancer.

\section{Epigenetics alteration of gastric cancer}

The epigenetic driver genes such as myeloid/lymphoid or mixed-lineage leukemia $(M L L)$ s, AT-rich interaction domain 1A (ARID1A) and enhancer of zeste 2 polycomb repressive complex 2 subunit $(E Z H 2), \mathrm{P} 300 / \mathrm{CBP}$-associated factor $(P C A F)$, and lysine demethylase 6A (KDM6A; $U T X)$, and their downstream targets are frequently mutated and affected in GACs [12].

Cancer progression is caused by phenomena of epigenesis, such as tumorigenic-enhancer reactivation in both normal cells and cancer cells. CSC-targeted anticancer therapies for the purpose of inhibiting epigenetic modifiers are promising. For example, inhibitors of DNA methyltransferase (DNMT), histone deacetylase (HDAC), 


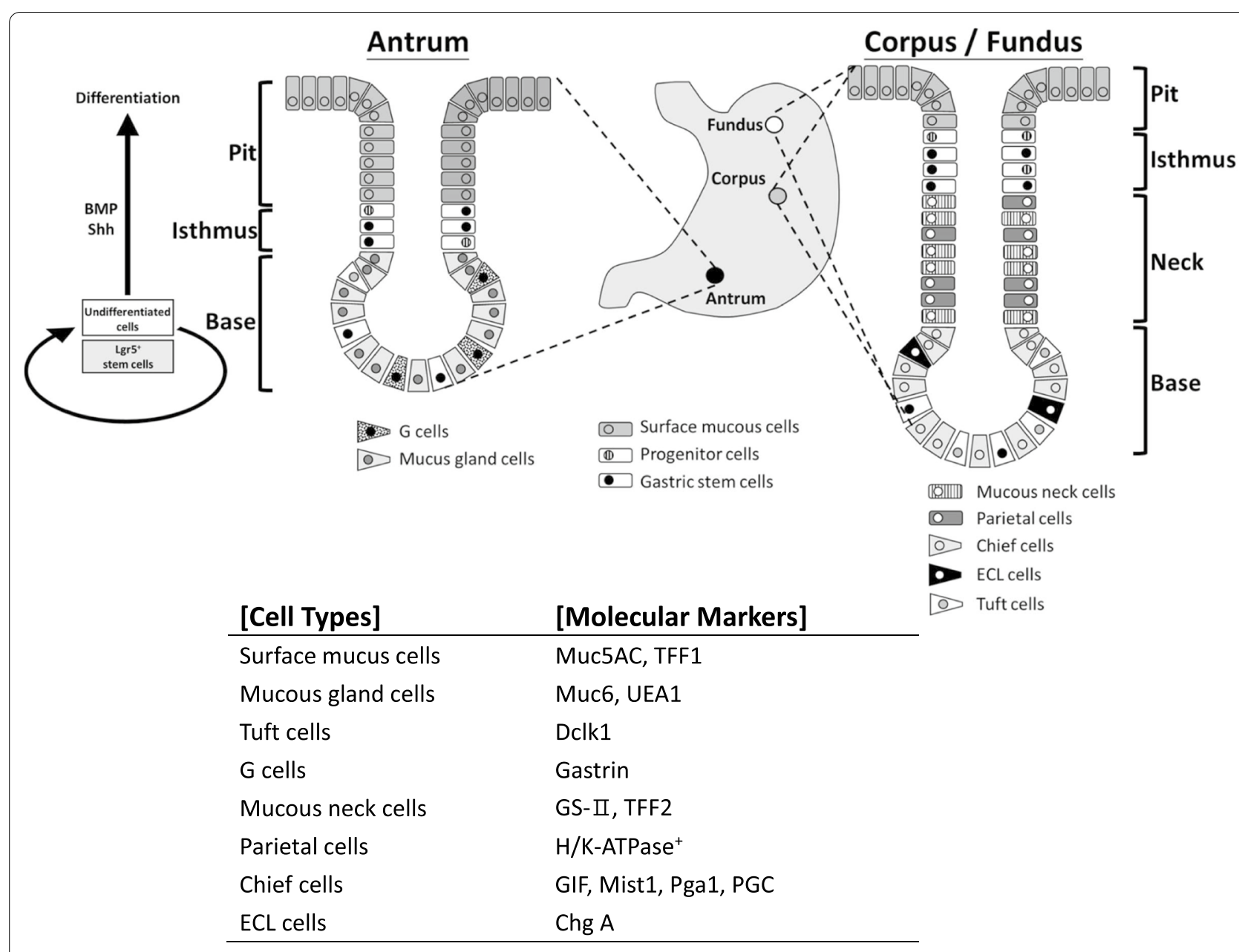

[Gastric stem cells \& progenitor cells markers in different regions]

\begin{tabular}{llc} 
& \multicolumn{1}{c}{ [Antrum] } & \multicolumn{1}{c}{ [Corpus/Fundus] } \\
\hline Isthmus & Villin promoter, Lrigl, Bmi1 & TFF2 mRNA, Mist1, eR1, Lrigl, Bmi1 \\
& & \\
Base & $\begin{array}{l}\text { Lgr5, Sox2, Cck2R, eR1, Axin2, Lrigl, } \\
\text { Aqp5 }\end{array}$ & Sox2, TFF2, Troy' chief cells, Lrigl \\
& A
\end{tabular}

Fig. 1 Gastric stem cells in human antrum and corpus/fundic area. In the antrum, Notch signaling affects the balance between proliferation and differentiation in the human stem cells. Both gastrin and acetylcholine are niche factors. In corpus/fundic area, Shh and BMPs are restricted to the area of isthmus and neck of fundic gland to affect LGR5 ${ }^{+}$stem cells for differentiation. Stromal cells (CXCL12 ${ }^{+}$endothelial- and CXR4 ${ }^{+}$innate lymphoid-cells) contribute to the corpus/fundic stem cells niches partially through production of Wnt5a. EGF, FGF10 and WNT play critical roles in control of self-renewal and pluripotency of gastric stem cells in the base gland of antrum and the isthmus of corpus/fundus $[3,5]$. Each cell type and molecular markers are listed. Muc5AC, mucin 5AC; TFF1, trefoil factor 1; GS-II, Griffonia simplicifolia II;TFF2,trefoil factor 2; Muc6, mucin 6; UEA1; Ulex europaeus agglutinin 1; GIF, gastric intrinsic factor Pga1, pepsinogen 1; PGC, pepsinogen C; ChgA, chromogranin A; Dclk1, double cortin-like kinase 1

bromodomain, and extraterminal motif proteins have been permitted by the United States Food and Drug Administration and they are going to therapeutic trials for various malignant cancers [13]. The chromatin regulatory complexes of polycomb repressive group (PcG)/ trithorax group (TrxG) can control the reprogramming 

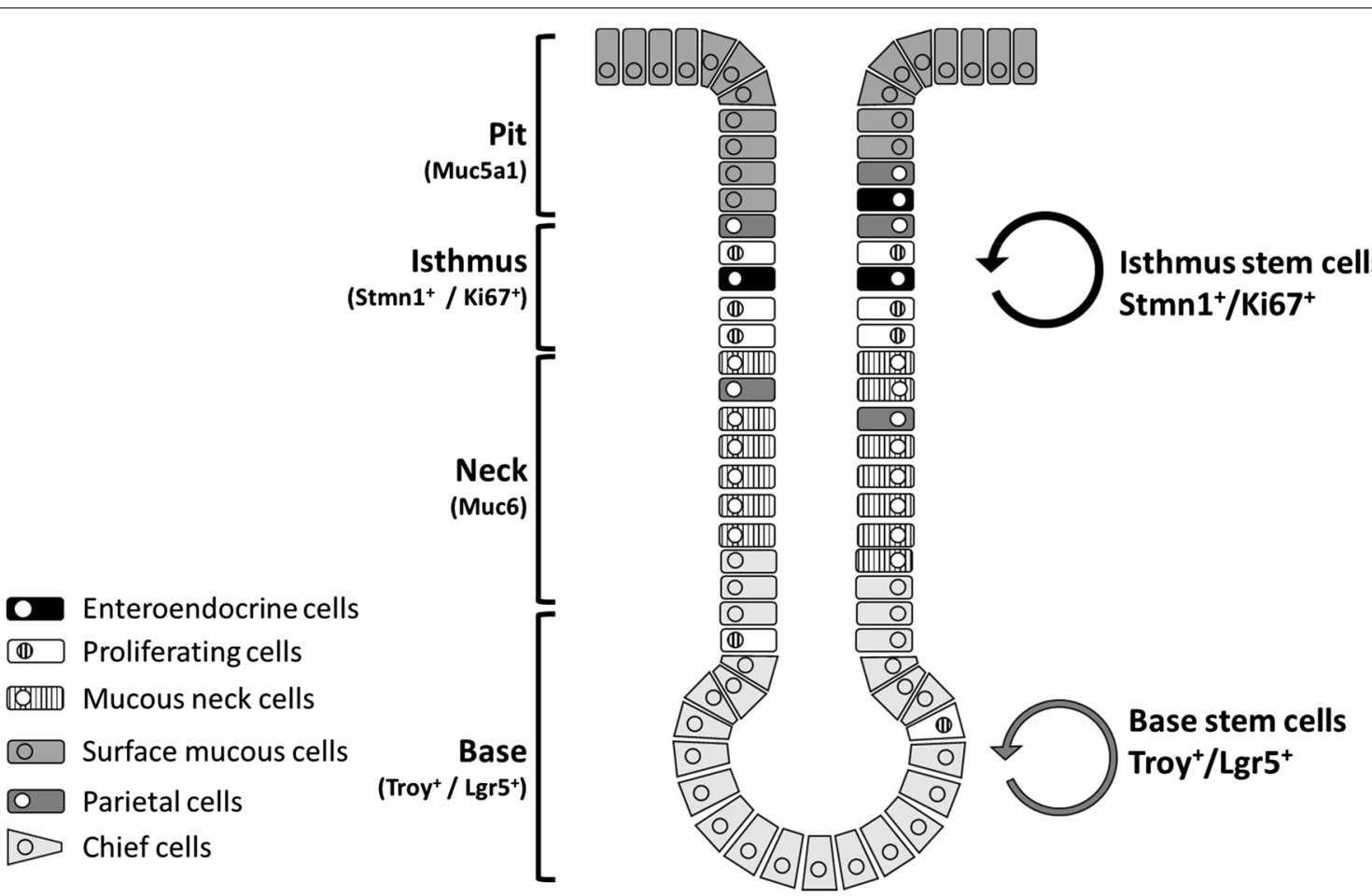

Fig. 2 Schematic representation of mouse gastric corpus gland. In mouse gastric corpus, two different stem cell population such as isthmus stem

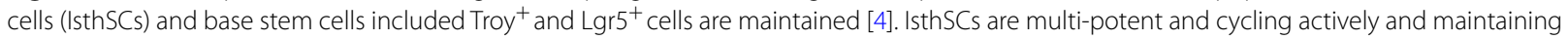
the pit-isthmus-neck regions through a process of stochastic self-renewal. IsthSCs are localized between pit and neck and are characterized as expressions of Stmn1 and Ki 67. As IsthSCs move to displace upward or downward from the Isthmus region and become sub-lineage restricted with co-expression of lower Muc5aca and Muc6 before terminal differentiation into the respective cell types, the gland base is maintained by TROY ${ }^{+}$or $\mathrm{LGR5}^{+}$(Chief) stem cells, which are mostly quiescent

Table 1 Comparison of gastric stem cells

\begin{tabular}{|c|c|c|c|}
\hline & $\begin{array}{l}\text { Antrum } \\
\text { (Human) } \\
{[\text { Ref. } 3,5]}\end{array}$ & $\begin{array}{l}\text { Isthmus } \\
\text { (Mouse) } \\
\text { [Ref. 4] }\end{array}$ & $\begin{array}{l}\text { Corpus/Fundus } \\
\text { (Human) } \\
{[\text { Ref. } 3,5]}\end{array}$ \\
\hline Location of cells & Isthmus, Gland base & Isthmus & Isthmus, Gland base, Chief cells \\
\hline Differentiation & Expand bidirectionally for isthmus & $\begin{array}{l}\text { At gland base stem cells migrate upward } \\
\text { from the basal zone }\end{array}$ & $\begin{array}{l}\text { Migrate into two independent zones; } \\
\text { Slow-cycling stem cells in the base and } \\
\text { active-cycling cells to the pit-isthmus- } \\
\text { neck region }\end{array}$ \\
\hline Markers & $\begin{array}{l}\text { (Isthmus) Lrig1, Bmi1 (Gland base) LGR5, } \\
\text { SOX2, CCK2R, CR1, AXIN2, AQP5 }\end{array}$ & $\begin{array}{l}\text { (Isthmus) Rapid cycling isthmus stem cells: } \\
\text { Stmn1, Ki67 } \\
\text { (Neck) weak Muc6 } \\
\text { (Pit) weak Muc5ac } \\
\text { (Base) Troy or Lgr5 }\end{array}$ & $\begin{array}{l}\text { (Isthmus) TFF2mRNA,MIST1, eR1, LRIG1, } \\
\text { BMI1 } \\
\text { (Gland base) SOX2, TFF2, LRIG1, } \\
\text { TROY+-Chief cells }\end{array}$ \\
\hline Offspring & $\begin{array}{l}\text { Surface mucous cells, Mucous gland cells, } \\
\text { G cells, Tuft cells }\end{array}$ & $\begin{array}{l}\text { Rapid cycling Isthmus Stem cells -Muc5ac, } \\
\text { Muc6 }\end{array}$ & $\begin{array}{l}\text { Surface mucous cells, Mucous neck cells, } \\
\text { Parietal cells, ECL cells }\end{array}$ \\
\hline Niche factors & Wnt, Notch, Gastrin, Ach, EGF, FGF10 & $\begin{array}{l}\text { A process of punctuated neutral drift } \\
\text { dynamics }\end{array}$ & WNT, BMPs, SHH, EGF, FGF10 \\
\hline
\end{tabular}

Human antrum and corpus/fundus stem cells were characterized by the location, markers and differentiation potency through niche factors as described in ref. 3 . Mouse isthmus stem cells were reported recently to commit the rapid cycling stem cells expressing Stmn1 and Ki67 [4]

of cancer cells, and they perform a critical role in the progression of CSCs [8]. A chromatin modifier, the linker histone variant $\mathrm{H} 1.0$, can control the cell division and promote the cancer cell differentiations. Therefore, H1.0 expression must have an obstructive property against tumorigenesis in vivo [14]. It has been demonstrated that 
Table 2 Human gastric cancer-related genes

\begin{tabular}{|c|c|c|c|}
\hline Genes & Names & Characteristics & References \\
\hline BUB1 & Budding is not inhibited by benzimidazoles & S/T kinase, Mitosis, Spindle checkpoint & [10] \\
\hline BUB1B & Budding is not inhibited by benzimidazole homolog beta & kinase in spindle checkpoint, cell cycle, mitosis & [10] \\
\hline $\mathrm{NCAPH}$ & Non-SMC condensin 1 complex subunit H & Condensin complex, Mitotic chromosome & [10] \\
\hline KIF14 & Kinesin family member 14 & Kinesin superfamily, Microtubule motor proteins & [10] \\
\hline KIF15 & Kinesin family member 15 & Kinesin superfamily, Microtubule motor protein & [10] \\
\hline KIF18B & Kinesin family member $18 \mathrm{~B}$ & Kinesin superfamily, Microtubule motor protein & [10] \\
\hline $\mathrm{KIF} 4 \mathrm{~A}$ & Kinesin family member $4 \mathrm{~A}$ & Kinesin superfamily, Microtubule motor proteins & [10] \\
\hline RACGAP1 & Rac GTPase activating protein 1 & $\begin{array}{l}\text { Component of centralspindlin complex, Cytokinesis, Cell } \\
\text { growth \& differentiation }\end{array}$ & [10] \\
\hline RAD-54L & DNA repair and recombination protein RAD54-like & $\begin{array}{l}\text { DEAD-like helicase superfamily, Repair of DNA double } \\
\text { strand breaks }\end{array}$ & [10] \\
\hline TPX2 & TPX Microtubule nucleation factor & Cell cycle, Mitotic control of PLK1, G $/$ M Transition & [10] \\
\hline CENPF & Centrosome protein $\mathrm{F}$ & $\begin{array}{l}\text { Associated with centrosome, Kinetochore complex, Chro- } \\
\text { mosome segregation }\end{array}$ & [10] \\
\hline TTK & Dual specificity protein kinase & Mitotic check point, Accurate segregation of chromosome & [10] \\
\hline SGO & Shugoshin & $\begin{array}{l}\text { Protection centromeric cohesion from cleavage during } \\
\text { mitotic prophase }\end{array}$ & [10] \\
\hline PLK4 & Polo family of $\mathrm{S} / \mathrm{T}$ protein kinase 4 & Control centriole duplication & [10] \\
\hline XRCC2 & $X$-ray repair cross complementing 2 & $\begin{array}{l}\text { A member of Rec A/Rad51 related protein family, Chromo- } \\
\text { some stability and repair DNA damage, DNA double } \\
\text { strand break }\end{array}$ & [10] \\
\hline Clorfl2 & Egl-9 family hypoxia inducible factor 1 & 4-hydroxyprolin in HIFa protein, Cellular oxygen sensor & [10] \\
\hline FN1 & Fibronectin & $\begin{array}{l}\text { Cell adhesion, Motility, Opsonization, Would healing, Cell } \\
\text { shape }\end{array}$ & [11] \\
\hline SERPINE1 & Serpin family member 1 & $\begin{array}{l}\text { Serine protease inhibitor superfamily, Inhibitor of tPA and } \\
\text { urokinase inhibitor of fibrinolysis }\end{array}$ & [11] \\
\hline SPARC & Secreted protein acidic acid cysteine rich & Cysteine-rich acidic matrix-associated protein & [11] \\
\hline MLLs & $\begin{array}{l}\text { Myeloid/Lymphoid or Mixed-lineage Leukemia protein } \\
\text { member }\end{array}$ & Methyltransferase of histone 3K4 & [12] \\
\hline ARD1A & AT-rich interactive domain-containing protein $1 \mathrm{~A}$ & SWI/SNF family, Helicase/ATPase. Chromatin remodeling & [12] \\
\hline $\mathrm{EZH} 2$ & Enhancer of zeste homolog 2 & $\begin{array}{l}\text { Histone-lysine-N-methyltransferase enzyme, Chromatin } \\
\text { remodeling }\end{array}$ & [12] \\
\hline PCAF & p300/CBP-associated factor & $\begin{array}{l}\text { Lysine acetyltransferase 2B (KAT2B), Transcriptional coactiva- } \\
\text { tor associated with p53 }\end{array}$ & [12] \\
\hline UTX (KDM6A) & Lysine -specific demethylase 6A & $\begin{array}{l}\text { Demethylation of Lysine residue of histone, specifically } \\
\text { H3K27 }\end{array}$ & [12] \\
\hline
\end{tabular}

Human gastric adenocarcinoma (GAC) and human gastric adenoma (GAS) were examined by the RNA sequencing and gastric cancer mRNA expression-based stemness index (mRNAsi) [see refs. 10-12]. The gastric cancer related genes are listed. mRNAsi was significantly upregulated in gastric cancer tissues compared to normal gastric tissues $(P<0.0001)$

the ARID1A, which is a subunit of the ATP-dependent chromatin remodeling complex switch/sucrose non-fermentable (SWI/SNF), functions to suppress the tumorigenesis of colon cancers, and its molecular loss enables the activation of the tumorigenic program for the formation of colon adenocarcinoma in mouse models [15].

\section{Tumor suppressor genes and pluripotency-inducing factors}

TP53 is a tumor suppressor gene which is involved in cell cycle arrest for DNA repair. In addition, it inhibits the mutation of genes during cell division and plays a critical role in apoptosis [16]. Inhibition of such tumor suppressor genes, i.e., P53 or the phosphatase and tensin homolog gene (PTEN), increased the efficiency of reprogramming to iPSCs [17]. Conversely, cyclin D inhibits to reprogram somatic cells to generate stem cells [18].

The expression of pluripotency-inducing genes, such as OCT4, SOX2, KLF4, an c-MYC (OKSM), is led by iPSCs, induces dedifferentiation in the body, and produces pluripotent cells in various bodies, teratomas, and dysplasias [19]. One of the reprogramming factors, c-MYC, is well known to overexpress in many cancers and inhibits differentiation, and promotes tumor formation in 
the absence of p53. As described earlier, OKSM, as well as NANOG and LIN 28, is protooncogenes, and stem cell-like cells inherently have carcinogenic potential. However, in colon and gastric carcinoma cells, KLF4 has $\mathrm{p} 21^{\mathrm{Cip} 1}$-dependent tumor suppression activity, thus inhibiting tumor progression and carcinogenesis [20].

The development of metastasis in CSCs is caused by their chemoresistance capacity, which is related to the expression of OCT4 and NANOG [21]. Therefore, targeting OCT4 or NANOG should be a rational strategy for therapeutic application in certain types of cancers. Short hairpin RNA (shRNA)-mediated NANOG knockdown in human gastric cancer cells decreased the characteristics of malignant cancer cells by increasing apoptosis and arresting cell cycle at the S phase [22]. Reexpression of stemness marker genes, such as $c-M Y C$, which is a WNT target, in the murine intestine caused tumor initiation together with dedifferentiation and triggered stem cell-like properties in gastric cells [19]. This tumorigenesis initiation relied on the activation level of Wnt and developed exclusively on augmentation of Wnt. Thus, a single signal pathway might be sufficient to commit the reprogramming of somatic cells to tissue-specific CSCs. These findings appear to prove the potential of the inhibition of stem cell marker genes together with synergistic chemotherapy for arresting tumorigenesis. Nevertheless, molecular, epigenetic, and cellular events in reprogramming of cancer cells do not appear to be this simple; rather, they are so complex.

\section{Cancer stem cells}

Cancer stem cells (CSCs) have been suggested to elucidate their properties of self-renewal properties via clonal cancer progression and clonal long-term repopulation [23]. CSCs have also been identified in glioblastoma and breast carcinomas $[24,25]$ since the presence of CSCs was firstly identified in acute myeloid leukemia [26]. In contrast to other cancer cells, CSCs can generate cancer cells overtly and repopulate progenitor cells indefinitely. The intratumor heterogeneity may be due to the various grades of differentiation ability between the CSCs and their progeny. Moreover, CSCs comprise less than $5 \%$ of cell populations which express a CD44 and respond to the epithelial surface antigen [27]. The combination of CD44 and CD24 was identified as an effective gastric CSC marker [28]. CD133 was first used to isolate CSCs from colon carcinoma [28]. Subsequently, another study showed that CD133 is not restricted to CSCs [3, 29]. The combination of epithelial cell adhesion molecule (EpCAM) with CD44 or CD54 with CD44 was also used for the isolation of gastric CSCs [29]. Moreover, in gastrointestinal cancers, CSCs are mostly positive for LGR5, because LGR5 ${ }^{+}$cells could produce gastric cancers [30].
A cancer treatment strategy involving extermination of most CSC populations using antibody-drug conjugates (ADCs) against specific CSC surface markers has been established. Studies using ADCs have excluded LGR5 ${ }^{+}$ CSCs, and ADCs have shown an anticancer potential in mouse intestinal cancer models [30].

Genetic and single-cell RNA sequencing studies showed that the heterogeneity of gastric cancer cells can be explained using the following two models: (1) the clonal evolution model and (2) a combination of the hierarchical and stochastic theories models [31]. The clonal evolution model suggests that driver mutations contribute to the expansion of cancer clonal cells by conferring a fundamental growth advantages to these cells. The recurrent genetic changes alter the phenotypes and functional characteristics of gastric cancer cells, which enables them to adapt to their cancer cells to their environments, suggesting a critical role of clonal evolution in gastric cancer to generate the heterogeneity and development. The combination model proposes adaptation of the cancer cells to their environment by changes in their gene expression patterns and generation of various subclones. Primitive CSCs have the natures of unlimited self-renewal and multilineage differentiation capacity. This results in the hierarchical structure of tumors. These CSCs evolve into different subclones and then sometime to evade the immunological system. Furthermore, the dominant clones produce their respective hierarchical cancer cells in the tumor areas, while other remaining cells are removed. These CSCs from models (i) or (ii) are required for the cancer microenvironments, such as the niches, to maintain the properties and plasticity of CSCs. Thus, as described above, studying the interaction between CSCs and their niches is critical for understanding the progression of the gastric cancer cells [31]. Moreover, the epigenetic regulation and signaling pathways also affect the development of CSCs and their niches. Here, we introduce an approach using three-dimensional (3-D) organoids to understand the interaction between gastric cancer CSCs and niches. These organ-level interactions will be investigated further to understand how the gastric cancer develops and progress, and how the gastric CSCs and the microenvironments interact to commit the tumor program. The use of gastric SCs and gastric CSCs and their organoids are useful for study of regeneration and the therapeutics application as well as cancer prevention (Fig. 3).

\section{Tumorigenic or tumor-suppressive potential of reprogrammed pluripotent gastric cancer cells}

Induced reprogramming of malignant (chronic myeloid leukemia) cells with abnormal or deleted p53 raised the efficiency of the generation of iPSCs and the frequency 


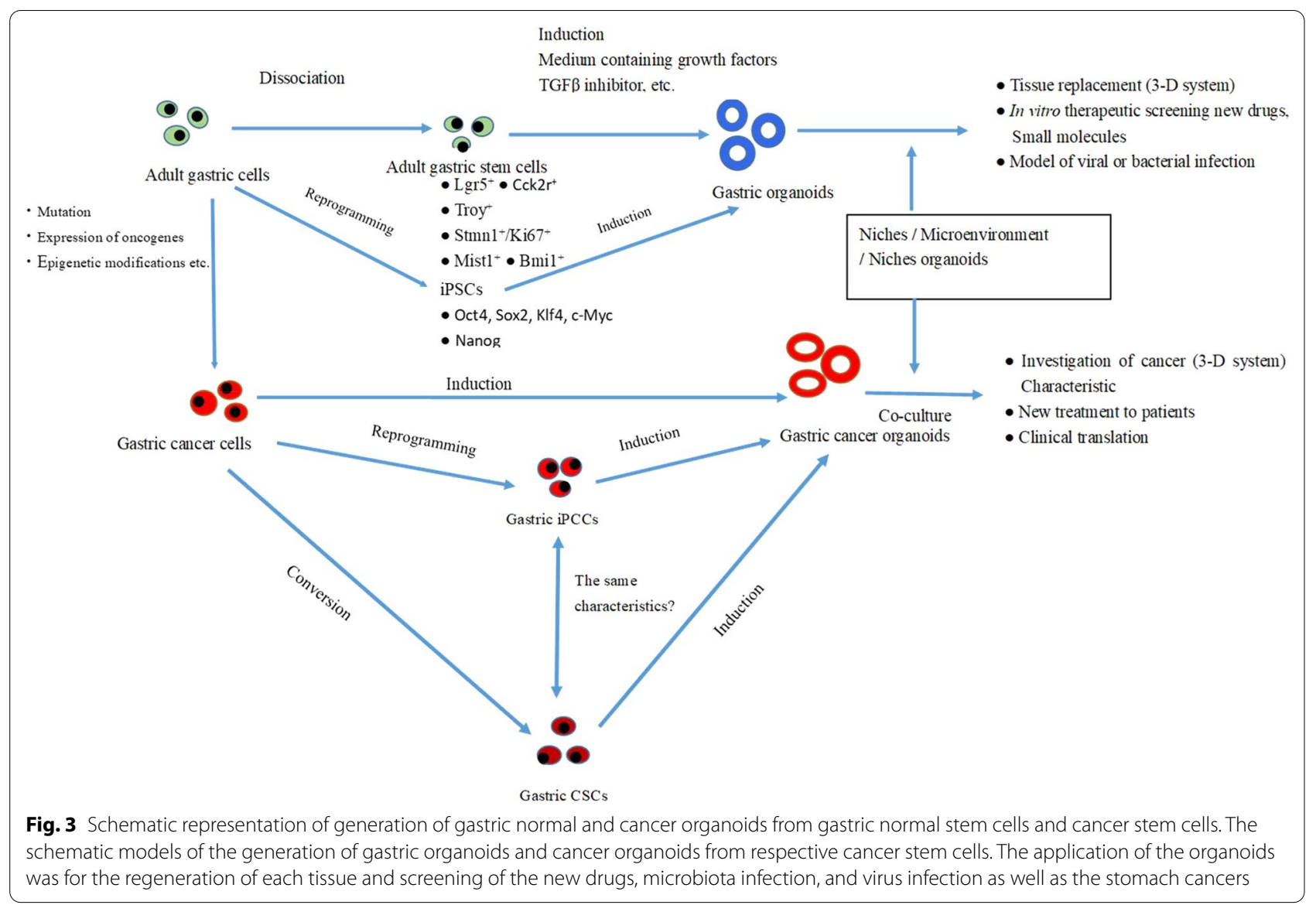

of tumor formation after the transplantation of these reprogrammed malignant cells into animals. Reprogrammed iPSCs acquired insensitivity to treatment with the kinase inhibitor imatinib [32]. In the strict sense, it may be better to prescribe these cancer cellderived iPSCs as induced pluripotent cancer stem cells (iPCSCs) or induced pluripotent cancer cells (iPCCs) to distinguish the normal iPSCs derived from noncancerous, healthy cells. Immediately after the successful establishment of iPSCs from human somatic cells [9], this reprogramming method was applied to several types of cancer cells to examine alterations in the tumorigenesis of iPCCs [33]. Miyoshi et al. performed to reprogram human gastrointestinal cancer cell lines, and eight iPCC (or iPCSC) lines were established from 20 cell lines by overexpressing OKSM, LIN28, and NANOG with the addition of shRNAs for tumor suppressor genes [33]. The resultant iPCCs were less tumorigenic compared with their parental cells. Several articles have reported the lower success rate in the generation of iPCCs among similar types of cancer cell lines [34]. Moreover, the lower efficiencies of cancer cell reprogramming are another problematic research subject. These lower efficiencies might be caused by various intricate mechanisms that are involved in the induction of cancer cell reprogramming $[33,34]$.

As a model for investigating carcinogenesis, the application of cancer cell reprogramming must be worthwhile regarding its operation. A few reports have demonstrated the repression of tumorigenicity in reprogrammed iPCCs derived from cancer cells, including gastrointestinal cancer $[33,35]$. In our study that used OCT4 and JDP2 as pluripotency-inducing reprogramming factors, the iPCCs generated from a gastric cancer cell line inhibited the tumorigenic capacity of xenografts in SCID mice compared with that of parental CS12 cells by switching off the expression of the bone morphogenic protein 7 (BMP7) [36]. A growing body of experimental findings revealed that the high-level expression of BMP7 was correlated with its oncogenic function of increasing tumor invasion and metastasis, which led to the proposal that the reprogramming of gastric cancer cells might be a good option for the development of cancer research, with a possible impact on future therapies and the prevention of cancer initiation. In contrast, we generated iPCCs from a DAOY medulloblastoma cell lines by introduction of 
the same combination of OCT4 and JDP2 as reprogramming inducers; these iPCCs exhibited a higher tumorigenic potential in xenografts than did the parental DAOY cells, and the generation of a CSC-like state via forced expression of JDP2 was noted in that experiment. This difference in tumorigenic capacity between cancer cell lines may be linked to the heterogeneity of plasticity and/ or epigenetics. Noncoding RNA alterations, chromatin alterations, and histone modifications near the mutated DNA regions are also master key events in the conversion of tumorigenic characteristics, which are often controlled by special DNA elements named super-enhancers [6]. Thus, the protocols used for reprogramming cancer cells must be optimized according to the respective types of cancer.

\section{Generation of fundic organoids}

The generation of HGOs in vitro is essential for the similar manipulation of growth factor signaling to that in vivo. To produce foregut tissue (spheroids) from human pluripotent stem cell (hPSC)-derived definitive endoderm, Noggin inhibits BMP to induce the enhanced expression of SOX2 and repressed expression of CDX2 [6]. The changes from 2-dimensional (2-D) endoderm into 3D-gut spheroids are performed by the activation of Wnt and FGF4 [6]. To promote antral identity with PDX1 expression, the 3-D spheroids require to inhibit BMP furthermore and to activate retinoic acid (RA) pathway, together with enhancing epidermal growth factor (EGF) signaling. Thus, this cascade is essential for the development of antral-specific organoids.

The protocol of formation of fundic organoids was more complexed because the signals that commit to the formation of the fundus were not known. The canonical Wnt signaling is essential to identify fundic specification. The pro-fundic role of Wnt signaling is distinct from its developmental role of repressing the anterior endoderm the early stage, thus exemplifying the concept that the function of signals has different roles at diverse developmental stages. Continuous activation of WNT is sufficient for promotion of a fundic epithelial fate by inhibiting PDX1 in posterior foregut cultures and results in the generation of fundic organoids expressing markers of mucus and chief cells. But it is not enough to promote the differentiation of parietal cells, which is needed as an additional process to inhibit MEK and activate BMP signals at the final stage of cultivation (days 30-34).

\section{Adult stem cells (ASCs) and pluripotent stem cells (PSCs) allow to establish the gastric organoids}

Gastric organoids have been generated from stomach tissue-derived ASCs and PSCs. The main differences between these two types are the presence of mesenchymal cells in the cultivation of PSC-derived organoids. PSC-derived organoids are needed a stepwise protocol that differentiates PSCs into the targets identically; in contrast, ASC-derived gastric organoids require only a simple growth factor-enriched medium. Thus, the length of the cultivation needed to establish the organoids from PSCs is 1 or 2 months, whereas that of ASCderived organoids is 1 or 2 weeks.

Mouse gastric organoids derived from ASCs were established from antrum glands containing $\mathrm{LGR}^{+}$stem cells. The procedure used in this experiment was the same as that employed for the intestinal organoid culture system, with addition of FGF10 and gastrin [37]. The expression of pepsinogen $\mathrm{C}$ as a marker of chief cells and MUC6 as a marker of mucus neck cells was also identified. The decreased concentration of WNT resulted in generating the differentiated lineages of endocrine cells and mucous pit cells, but not of parietal cells. Similar conditions for cultivation were used for producing murine corpus organoids from $\mathrm{TROY}^{+}$stem cells [38]. These organoids expressed the markers of chief cells and mucus neck cells. In the absence of FGF10, NOGGIN, and WNT, differentiated pit cells could be found, whereas endocrine or parietal cells were not detected.

Human antral organoids can be generated using the mouse procedure described previously [39]. The generation of human corpus organoids with successful long-term proliferation required the inhibition of TGF $\beta$ signaling by A83-01 (an activin receptor-like kinase ALK5 inhibitor) [40].

Gastric organoids containing both epithelial and mesenchymal cells can be generated by the differentiation of PSCs. McCracken et al. reported the differentiation procedure from human PSCs to gastric organoids firstly [6, 41]. Addition of activin A and BMP4 caused human PSCs to differentiate into endoderm. Activin A stimulated Nodal, which is critical for formation of foregut. Posterior foregut formation was succeeded by addition of FGF4 and WNT or CHIR99021, which is a glycogen synthase kinase 3 (GSK3) beta inhibitor that activates WNT signaling. Noggin was additionally required to inhibit the BMP signal and generate the stomach-derived foregut. The embedding of these cells into the extracellular matrix helped produce 3-D foregut spheroids. Differentiation of antrum was performed by incubation of retinoic acid (RA) and EGF. The complete differentiation process required approximately 34 days to produce neutral organoids containing enteroendocrine cells, mucus neck, and pits [6].

To develop the foregut into corpus organoids, supplementation with CGIR99021, EGF, and FGF10 was also required. To produce parietal cells, the medium was subsequently added by BMP4 and the MEK inhibitor 
PD0325901 [41]. Differentiated corpus organoids comprised a variety of key cells included chief, endocrine, mucus neck, and parietal cells [44]. Noguchi et al. generated organoids from murine PSCs using a stepwise differentiation protocol [42]. The PSC-derived embryoid bodies were treated with Noggin, sonic hedgehog $(\mathrm{SHH})$, and the WNT antagonist Dickkoph 1 (DKK1). The mutual control of SHH activation and WNT inhibition allowed the formation of tube-like structures and spheroids that mimicked the structure of the early stomach. The embedding of spheroids resembled the early stomach-like matrix by adding FGF10, NOGGIN, WNT, and R-SPONDIN and allowed corpus gland formation after approximately 60 days.

A co-culture of ASC-derived organoids with mesenchymal cells overcomes the limitation of ASC-derived organoids inherent to their epithelial composition [43]. The addition of mesenchymal niche cells led to the production of all type cells of the stomach epithelium included parietal cells, although they were found only for a limited time.

Normal gastric organoids also represent a good model system for translational studies. Organoids can be used to recapitulate development of organs in vivo and represent a good model system to investigate Helicobacter pylori infection [44]. In addition, organoid systems have been successfully used for disease modeling by the recent gene editing techniques, such as CRISPR/Cas9 [45] and CRISPR/HAT [46]. Thus, we should focus on the generation of human biobanks for basic and clinical use of patient-derived gastric cancer organoids.

\section{Patient-derived gastric cancer organoids}

Five independent researchers reported the generation of gastric cancer organoids (Table 2). Seidlitz et al. made a biobank composed of human gastric cancer organoids (20 organoids) with a molecular characterization of four additional organoid lines [47]. Vlachogiannis et al. generated a patient-specific biobank comprising different gastrointestinal cancers, including four gastric cancer organoids [48]. Nanki et al. produced a biobank of 37 gastric cancer organoids [49]. They clarified the effect of different niches on the support of individual cancers. Recently, a largest biobank was reported by Yan et al. [50], consisting of 46 organoid lines. Of interest, this report compared the organoids derived from multiple biopsies of the same patient, thus allowing the characterization of subclones within the primary cancer. Ukai et al. generated and characterized 10 gastric cancer organoids from surgically resected specimens, four of which were 5-FU-resistant organoids [51]. They identified the role of KHDRBS3 as a gene involved in drug resistance in gastric cancer organoids. Various protocols using different enzymatic digestions have been used, such as dispase II and collagenase XI [50], EDTA and TrypLE [48], Liberase TH and TrypLE Express [49], collagenase and hyaluronidase [50], or Partec CellTrics (Sysmex, Hyogo, Japan; [51]). Growth medium composition also varied among the protocols (Table 2). To avoid cell contamination in the organoid preparations, Nanki et al. established a new method to enrich the cancer organoids by inhibiting various signals, i.e., RAS-phosphoinositide 3-kinase (PI3K), RHO, TGF $\beta$, TP53 which are not tolerated by nonmutated normal organoids [49]. This protocol resulted in an increase in the efficiency of cancer organoid generation, from 55 to $75 \%$. In contrast, Yan et al. enriched cancer organoids by microscopical selection, and by treatment with nutlin3a in the case of TP53 mutation (Table 3) [50].

\section{Morphological features}

Seidlitz et al. reported the generation of cystic organoids with a multilayered wall that exhibited a growth pattern with noncoherent grape-like compact cell cluster without lumen [47]. Nanki et al. and Yan et al. [49, 50] grouped them into three subtypes, as shown in the Lauren classification [52]: (1) a solid subtype derived from diffused gastric cancers with amorphous solid configurations and a dis-cohesive growth pattern, (2) a glandular subtype derived from intestinal cancers with a single lumen, and (3) a mixed subtype [49-52].

A study between phenotype and genotype was reported by Nanki et al., who knocked out $C D H 1$ using CRISPR/ Cas9, which allowed the phenotypical alteration of organoids from normal cystic structures to slide structures with migration activity, resembling patient-specific organoids with a $C D H 1$ mutation [49]. This trial should be continued to address the relationship between molecular mechanisms and the morphological and histological alterations of the HGOs.

\section{Molecular characterization}

The Cancer Genome Atlas Research Network [53] demonstrated the existence of the MSI, GS, CIN, and EBV subtypes among patient-specific gastric cancers. In addition, a $96 \%$ overlap in the mutational spectrum between organoids and parental organs was identified [47, 48]. Yan et al. reported varying degrees of heterogeneity in gastric cancer by comparing patient-specific gastric cancer organoids from primary tumors and lymph node metastases [50]. A patient-specific gastric cancer organoid library of different tumors from an individual patient generates a new tool that can be used to investigate the consequent outputs of intra-tumoral heterogeneity. Nanki et al. investigated the correlation between phenotype and genotype by focusing on the niche-derived factor dependences and genetic alterations [49]. Ki-ras2 Kirsten 
Table 3 Patient-specific cancer organoids biobank characteristics

\begin{tabular}{|c|c|c|c|c|c|}
\hline & $\begin{array}{l}\text { Vlachogiannis et al. } \\
\text { [48] }\end{array}$ & Seidlitz et al. [47] & Yan et al. [50] & Nanki et al. [49] & Ukai et al. [51] \\
\hline Tissue origin & $\begin{array}{l}\text { Ultrasound CT-guided } \\
\text { biopsy }\end{array}$ & Surgical resection & Surgical resection & $\begin{array}{l}\text { Surgical resection } \\
\text { Endoscopic biopsy } \\
\text { Ascites punctures }\end{array}$ & $\begin{array}{l}\text { Surgical resection } \\
\text { Endoscopic biopsy }\end{array}$ \\
\hline \multicolumn{6}{|l|}{ Organoid library } \\
\hline Cancer & 4 & 20 & 46 & 37 & 20 \\
\hline Normal & - & 3 & 17 & 6 & 10 \\
\hline $\begin{array}{l}\text { Patients with clinical } \\
\text { trails }\end{array}$ & + & - & - & - & - \\
\hline Tissue digestion & $\begin{array}{l}\text { TrypLE }(2 \mathrm{x}) \\
\text { EDTA }(1 \mathrm{mM})\end{array}$ & $\begin{array}{l}\text { Dispase II }(1 \mathrm{mg} / \mathrm{ml}) \\
\text { Collagenase }(0.6 \mathrm{mg} / \\
\mathrm{ml})\end{array}$ & $\begin{array}{l}\text { Collagenase XI ( } 0.1 \mu \mathrm{g} / \\
\mu \mathrm{l}) \\
\text { Hyaluronidase }(20 \mu \mathrm{g} / \\
\mu \mathrm{l})\end{array}$ & $\begin{array}{l}\text { Libease H } \\
\text { TrypLE Express }\end{array}$ & $\begin{array}{l}\text { Partec CellTrics (Sysmex, } \\
\text { Hyogo, Japan) } \\
\text { EDTA }(1 \mathrm{mM})\end{array}$ \\
\hline \multicolumn{6}{|l|}{ Medium composition } \\
\hline WNT3A & $100 \mathrm{ng} / \mathrm{ml}$ & $50 \%$ & $50 \%$ & $25 \%$ & $25 \%$ \\
\hline R-spondin & $500 \mathrm{ng} / \mathrm{ml}$ & $10 \%$ & $10 \%$ & $1 \mu \mathrm{g} / \mu \mathrm{l}$ & $1 \mu \mathrm{g} / \mu \mathrm{l}$ \\
\hline Noggin & $100 \mathrm{ng} / \mathrm{ml}$ & $10 \%$ & $10 \%$ & $100 \mathrm{ng} / \mathrm{ml}$ & $100 \mathrm{ng} / \mathrm{ml}$ \\
\hline B27 & $1 x$ & $1 x$ & $1 x$ & $1 x$ & $1 x$ \\
\hline N2 & $1 x$ & $1 x$ & - & - & - \\
\hline Nicotinamide & $4 \mathrm{mM}$ & $10 \mathrm{mM}$ & - & - & - \\
\hline NAc-Cys & - & $1 \mathrm{mM}$ & $1 \mathrm{mM}$ & $1 \mathrm{mM}$ & $1 \mathrm{mM}$ \\
\hline hFGF10 & $10 \mathrm{ng} / \mathrm{ml}$ & $200 \mathrm{ng} / \mathrm{ml}$ & $200 \mathrm{ng} / \mathrm{ml}$ & $50 \mathrm{ng} / \mathrm{ml}$ & $50 \mathrm{ng} / \mathrm{ml}$ \\
\hline hFGF10-basic & $10 \mathrm{ng} / \mathrm{ml}$ & - & - & - & - \\
\hline mEGF & $50 \mathrm{ng} / \mathrm{ml}$ & $50 \mathrm{ng} / \mathrm{ml}$ & $50 \mathrm{ng} / \mathrm{ml}$ & $50 \mathrm{ng} / \mathrm{ml}$ & $50 \mathrm{ng} / \mathrm{ml}$ \\
\hline Gastrin & $10 \mathrm{nM}$ & $1 \mathrm{nM}$ & $1 \mathrm{nM}$ & $10 \mathrm{nM}$ & $10 \mathrm{nM}$ \\
\hline A83-01 & $0.5 \mu \mathrm{M}$ & $2 \mu \mathrm{M}$ & $2 \mu \mathrm{M}$ & $500 \mathrm{nM}$ & $500 \mathrm{nM}$ \\
\hline Y-27632 & $10 \mu \mathrm{M}$ & $\begin{array}{l}10 \mu \mathrm{M} \text { (only for initial } \\
\text { stage) }\end{array}$ & $10 \mu \mathrm{M}$ & - & $\begin{array}{l}10 \mu \mathrm{M} \text { (only for initial } \\
\text { stage) }\end{array}$ \\
\hline Prostaglandin E2 & $1 \mu \mathrm{M}$ & - & - & - & - \\
\hline SB202190 & $5 \mu \mathrm{M}$ & - & - & - & - \\
\hline $\begin{array}{l}\text { Selection of cancer } \\
\text { organoids from } \\
\text { prevent normal } \\
\text { organoid-over- } \\
\text { growth }\end{array}$ & - & - & + & + & + \\
\hline Selection via & & & $\begin{array}{l}\text { 1. Microscopically } \\
\text { organoid picking } \\
\text { 2. Nutlin3a }(10 \mu \mathrm{M})\end{array}$ & $\begin{array}{l}\text { 1. Plus Nutlin3a } \\
(3 \mu \mathrm{M}) \text { minus } \\
\text { Y-27632 } \\
\text { 2. Minus A83-01 } \\
\text { plus TGF }(10 \mathrm{ng} / \\
\text { ml) } \\
\text { 3. Minus EGF and } \\
\text { FGF18 }\end{array}$ & $\begin{array}{l}\text { 1. Microscopically orga- } \\
\text { noid picking } \\
\text { 2. Drug resistant GCOs } \\
\text { clones with selected } \\
\text { by 5-FU, puromycin, } \\
\text { and G418 }\end{array}$ \\
\hline
\end{tabular}

Recent five independent groups reported the human gastric organoid preparation [see ref. 46-50] and compared the culture conditions

+ :Yes, done -: none or not specified

rat sarcoma viral oncogene homolog (KRAS) mutation and RTK amplification, similar to that observed for the erb-b2 receptor tyrosine kinase 2 (ERBB2) or $E R B B 3$, led to the acquisition of independency from both EGF and FGF. The high expression of epiregulin (EREG), a ligand of EGFR, mediated the independence from EGF and FGF, suggesting an EREG-dependent autocrine loop.
The inhibition of TGF $\beta$ and BMP is important for the growth of the organoids. Treatment of organoids with mutations in the TGF $\beta$-receptor 2 (TGFBR2) and the SMAD family member 4 (SMAD4) genes with TGF $\beta$ and BMP4 did not affect their proliferation rate. Some cancer organoids without any mutations in the genes mentioned above were resistant to stimulation with TGF $\beta$ and BMP4, thus prompting the search for additional 
nongenetic mechanisms that allow tolerance toward TGF $\beta$ and BMP among patient-specific gastric cancer organoids [45]. Thus, this mechanism should be explored further to identify target genes.

WNT and R-spondin are also critical for the successful proliferation of normal gastric organoids. Thus, the gastric cancer organoids acquire WNT independently during tumor progression, e.g., by mutation of the adenomatous polyposis coli (APC) gene. Another mechanism consisting in the activation of WNT ligand production allows the autocrine stimulation of the tumor using an inhibitor of WNT ligand production [54]. R-spondin binds to LGR4/5 and stabilizes the frizzled and LRP as WNT receptors. In the absence of R-SPONDIN, both RNF43 and ZNRF3 are capable of ubiquitinating WNT receptors [53]. RNF43 mutations are detected in only 5\% of microsatellite-stable tumors, but exhibit a high mutation ratio in MSI-subtype patients (55\%) [55]. Of interest, several stomach and intestinal cancer organoids carrying the single RNF43 mutation remained R-SPONDIN dependent [53]. Subsequent genetic studies revealed that double mutations, homologous deletions, and downregulation of the RNF43 mRNA and the corresponding homolog of ZNRF3 caused R-SPONDIN independently. Interestingly, this was also observed for a RNF43D300Y single mutation. Thus, Wnt receptor regulators and TGF $\beta$-BMP signaling are critical for the growth of cancer organoids.
Several critical growth factors are important for the growth and proliferation of gastric organoids

To clarify the fidelity of human organoid models, we have noted several key issues for the cultivation and differentiation of normal and cancerous organoids (Unpublished data; Ref. [5]). (1) Effect of ROCK inhibition: RHO kinase inhibitor was added to inhibit the anoikis and apoptosis observed previously in purified colonic epithelial cells. This is absolutely required for organoid growth from the establishment stage (Fig. 4). (2) Effect of GSK inhibition: treatment with CHIR-99021 (a GSK inhibitor) and activated $\beta$-catenin-mediated transcription and induced phenotypic alterations in organoids. Of note, CHIR treatment with HDAC inactivation via the administration of valproic acid represented an effective method for the enrichment of LGR $5^{+}$cells in intestinal organoids. Thus, we used this protocol for 3 days and then removed it, which led to good growth of the organoids (Fig. 5). (3) Dose of niche factors: R-SPONDIN 1 concentration was similar in normal and cancer organoids $(10 \%)$, whereas the concentration of WNT3a $20 \%$ in cancer cases was better than $10 \%$ to obtain the good proliferation (Fig. 6). We are developing precise culture conditions for gastric organoids in vitro, to improve the accuracy of the generation of organoid models for future therapeutic and medical applications.
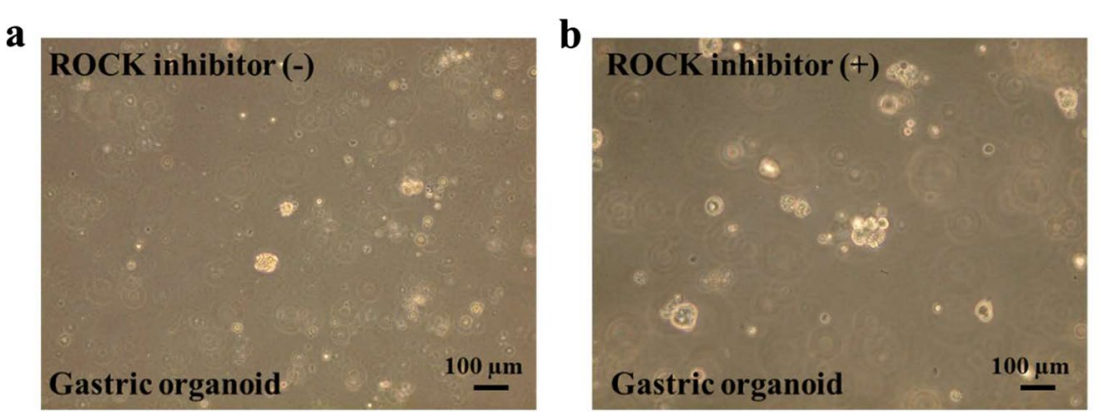

\section{C}

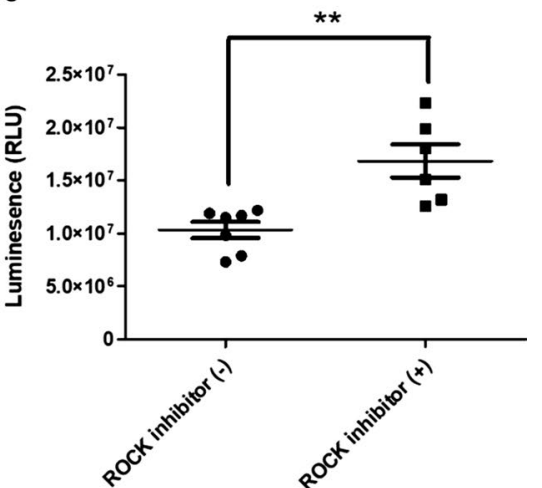

Fig. 4 Effect of ROCK inhibitor in gastric organoid culture. The rock inhibitor supplied in culture medium maintained the growth and morphologies of the organoids well and helped to avoid the culture-damages caused by the culture-environments. (a) The cultivation in the absence of the ROCK inhibitor (left lane) caused the growth of the organoids slowly. (b) Addition of ROCK inhibitor (10 $\mu \mathrm{M}$; right panel) resulted in the growth of the organoids 1.5-2.0-fold faster compared with the control organoids (left panel). Human adenocarcinoma of stomach organoid lines, HCM-BROD-0208-C16 cancer model primary adenocarcinoma of stomach was purchased from American Type Culture Collection (PDM-146 ${ }^{\mathrm{TM}}$; ATCC, VA, USA) and cultured as its recommended protocol [5] (bright view, scale bar $=100 \mu \mathrm{m}$ ). (c) The stomach organoids were generated by seeding in 96-well plates and grown 2 days ROCK inhibitor $(n=6)$ : Th organoids were incubated with CellTiter-Glo ${ }^{\circledR} 3 D$ reagent (G9681, Promega, Madison, WL, USA) prior to culture medium addition, and results were acquired to assay $\left({ }^{* *} P<0.01\right)$. 

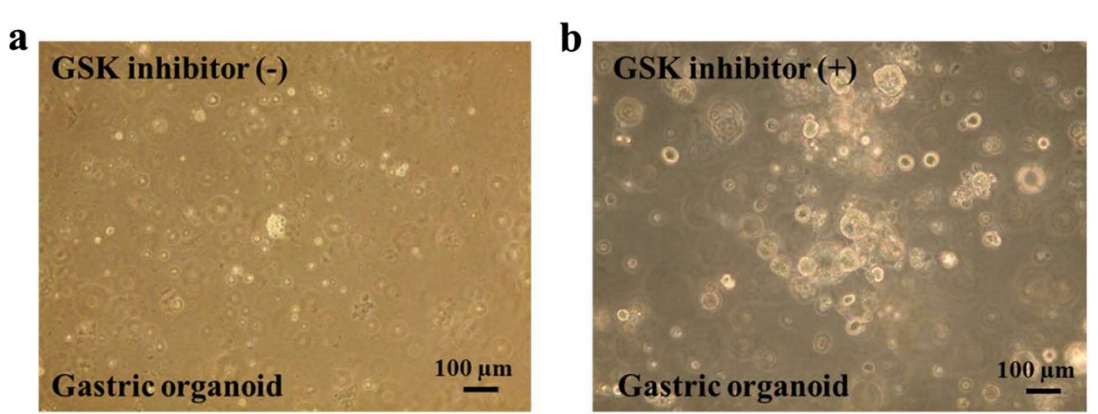

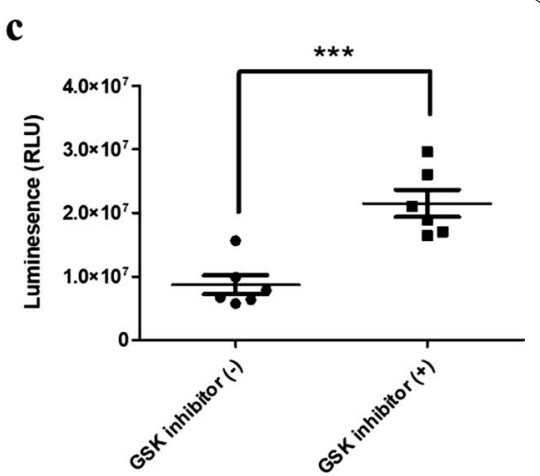

Fig. 5 Effect of GSK inhibitor in gastric organoid culture. The gastric organoids were fragile and damaged easily during the passaging process. (a) Organoids without GSK inhibitor resulted in apoptotic deaths and damaged the formation of the 3-D structure. (b) The addition of GSK inhibitor $(2 \mu \mathrm{M})$ supplied in every 2-3 days dramatically reduced and protected the cells-damage and stimulated the cell growth 2-threefold faster than in the control culture of the organoids. Human adenocarcinoma of stomach organoid lines, HCM-BROD-0208-C16 cancer model primary adenocarcinoma of stomach was purchased from American Type Culture Collection (PDM-146 ${ }^{\mathrm{TM}}$; ATCC, USA) and cultured as its recommended protocol [5] (bright view images, scale bar $=100 \mu \mathrm{m}$ ). (c) The stomach organoids were generated by seeding in 96-well plates and grown 2 days GSK inhibitor $(n=6)$ : Th organoids were incubated with CellTiter-Glo ${ }^{\circledR} 3 D$ reagent (G9681, Promega, Madison, WL, USA) prior to culture medium addition, and results were acquired to assay (*** $P<0.001)$
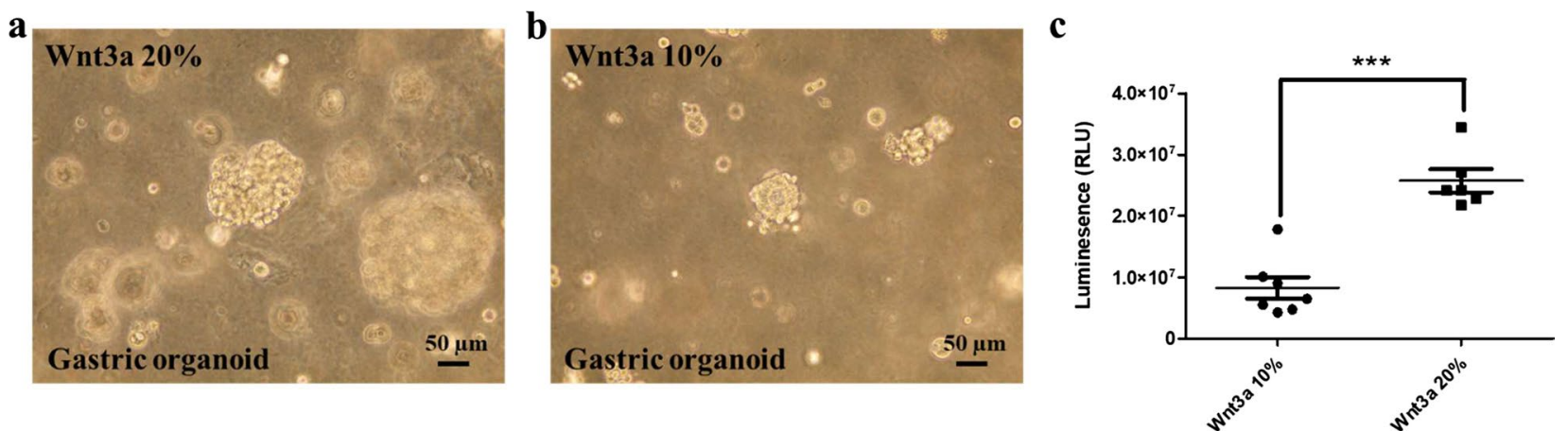

Fig. 6 Effect of niche factors in gastric organoid culture. The concentration of R-SPONDIN 1 in the gastric cancer organoids culture was 10\%, and the concentration of Wnt3a in the cancer organoids was 20\% (panel a) and 10\% (panel b). Human adenocarcinoma of stomach organoid lines, HCM-BROD-0208-C16 cancer model primary adenocarcinoma of stomach was purchased from American Type Culture Collection (PDM-146 ${ }^{\mathrm{TM}}$; ATCC USA) and cultured as its recommended protocol [5] (bright view images scale bar $=50 \mu \mathrm{m}$ ). (c) The stomach organoids were generated by seeding in 96-well plates and grown 2 days at different percentages of Wnt $(n=6)$. Th organoids were incubated with CellTiter-Glo ${ }^{\circledR} 3 \mathrm{D}$ reagent $(\mathrm{G} 9681$, Promega, Madison, WL,USA) prior to culture medium addition, and results were acquired to assay (*** $P<0.001)$,

\section{HGO application \\ Tissue engineering}

The use of organoids for clinical use as replacement tissues faces significant challenges in a near future. The stomach in humans is about $10 \mathrm{~cm} \times 30 \mathrm{~cm}$, while stomach organoids are in diameter $2-3 \mathrm{~mm}$. Thus, the requirement for new engineering of the tissue-growth formation for scaling-up is required because of the size gap between the tissues and the organoids of the stomach. One possible route should be in vivo growth, as described for intestinal organoids, which become larger than the original size [56]. The next problem lies in the complexity of the stomach. For example, HGOs contain an epithelium and mesenchymal layer and are deficient in ENS, which is crucial for stomach functions. This problem has been solved as reported in the case of human intestinal organoids. Previously, the successful incorporation of ENS within the mesenchyme layer of the human intestinal organoids was reported [56]. In the future, this will be carried out using HGOs. Another trial incorporated a vascular function into human lung organoids using a combination of endothelial cells and the immune system to generate human colonic and liver organoids, as reported [57]. Thus, the combination between different germ layers and different cell types within hPSC-derived gastrointestinal organoids might help understand the 
role of each layer and cell type in the creation of the tissue models.

\section{Helicobacter (H.) pylori infection}

Gastroenteritis, gastritis, gastroparesis, peptic ulcer disease, and stomach cancer are well-known diseases of the stomach, with the latter three being associated with the Bacillus bacterium H. pylori and gastritis [58]. These diseases are featured by inflammation and erosion, or irritation of the lining of the stomach. Patients with $H$. pylori infection have a $10-20 \%$ frequency of developing ulcers and gastric cancers at $1-2 \%$ risk. Among patients with ulcers, $95 \%$ of patients with duodenal ulcers and $80 \%$ of patients with gastric ulcers are positive for $H$. pylori infection [59]. Ulcers appears to arise in the corpusantrum transition area, as well as in the duodenum to study H. pylori pathogenesis [60].

HGOs derived from hPSCs provide a different model to investigate the stomach development. The signaling and interaction of the niches are studied by HGO-based platforms and might ideally be adapted to characterize the interactions of these various cell types during developing the human stomach. Finkbeiner et al. [61] reported the use of hSC-derived intestinal organoids to model a viral infection that supported the replication of rotavirus and the production of infection of both epithelial and mesenchymal components of the intestinal organoids, which was a promising platform not only for the study of the virus, but also other viral-related organisms. Forbester et al. [62] reported the injection of Salmonella enterica serovar typhimurium into the lumen of hPSCderived intestinal organoids and demonstrated that the bacteria can attack the intestinal epithelium, form intracellular Salmonella-containing vacuoles, and induce the production of cytokines. These vacuoles required oxygen consumption. Leslie et al. [63] also reported the merits of organoid-based infection. Thus, this platform could be useful for the study of improved treatments via drug screenings related to pathogens, for which there are no efficient therapeutic agents.

\section{Drug discovery and testing}

HGOs are also a new alternative tool to examine the toxicity of drugs and the in vitro screening of drugs and small molecules. For example, some drugs that block acid production are useful to inhibit acid secretion in fundic HGOs. It suggests that HGOs would be an ideal tool for searching for novel drugs and small molecules that regulate acid production [64]. This technology might provide a high-throughput method of investigating the efficacy and toxicity of drugs. Thus, technological improvements and challenges are key points in the development of $\mathrm{HGO}$ technologies for future therapeutic screening.

\section{Limitations of organoids}

There are several limitations to the present organoid technology. (1) Growth factors are, in some cases, generated by cell lines expressing exogenous genes that encode them, rather than the common commercially available growth factors. This will reduce the cost of maintenance but increase the experimental variation produced by the niche factors, which is a tedious procedure. (2) Another limitation is the practical use of Matrigel or other animalderived devices to enable cells to assemble into 3-D organoids. As the composition of these materials is not well defined, unforeseen problems might occur. Moreover, the removal of the Matrigel is critical for subsequent analysis, including extraction of DNA and RNA, CRISPRCas9 editing, or even cryopreservation. Gjorevski et al. [65] reported that a benefit of the high matrix stiffness to expand iPSCs through a YAP-mediated mechanism, while a soft matrix to increase the efficacy of lamininbased adhesion was required for iPSC differentiation and organoid generation. Such well-defined tools with minimal environment could accommodate the tissue dynamics that occur during the developmental processes. Another approach is the hydrogel-based platform that promoted the aggregation of progenitor cells into pancreatic organoids that maintained an islet morphology and function which were featured by enhanced expression of the PDX-1 and NKK6 [66]. (3) One more limitation is the lack of studies on immune interaction with gastric organoids. However, new technology to investigate the effect of immunoregulation on epithelial organoids was recently developed. Moreover, the technology employing fusion of organoids and coculture of multiple organoids has been developed recently [67]. The coculture of organoids with immune cells [68], ENS cells [56], and luminal factors such as bacterial cocultures [44] are important to study the microenvironmental regulation of CSCs. Many challenges should be remained in the long-term culture, and the preservation of immune cells could be stocked, and then, they are reconstituted. Supplements such as IL-2, antibodies against CD3 or CD28 might improve the long-term maintenance of immune cells, but we need the novel recapitulation of antitumor response by these combined organoids would be certainly necessary for robust validation $[69,70]$.

\section{Conclusion}

HGOs are used to be a promising tool because they are managed to recapitulate the exact stomach in vivo and allow unprecedented investigations of human development. Their translational applications will promote the 
diagnosis of patient pathologies and the development of screening techniques for pharmacological drugs in the future. Patient-specific HGOs are also precious tools as we encounter the era of personalized medicine. Large human organoid biobanks generated from diverse cancer tissues have been established and characterized in detail. A recent study performed by Kawasaki et al. [71] reported the establishment of a gastro-entero-pancreatic (GEP) neuroendocrine neoplasm (NEN) organoid biobank characterized by NKX2-5 expression and exhibiting WNT- and EGF-independent growth. These studies are also useful to address the de novo modeling of GEP-NEN through the genetic engineering of normal and tumor gastric organoids. Human organoid libraries have merits to investigate cancer characteristics and novel treatments in patients. In near future, patientderived organoids from normal tissues and cancer tissues can provide a useful bridge between molecular genetics based on genome wide research and clinical translation research.

\begin{abstract}
Abbreviations
ADCs: Antibody-drug conjugates; AMPK: Adenine monophosphate-activated protein kinase; APC: Adenomatous polyposis coli; ARIDIA: AT-rich interactive domain-containing protein 1A; ASCs: Adult stem cells; BMP: Bone morphogenic protein; CAFs: Cancer-associated fibroblasts; CSCs: Cancer stem cells; 3-D: Three-dimensional; DKK1: WNT antagonist Dickkoph 1; EC: Enterochromaffin; ECMs: Extracellular matrices; EGL: Enterochromaffin-like; ERBB2: Erb-B2 receptor tyrosine kinase 2; EREG: Epiregulin; ESCs: Embryonic stem cells; FDA: Food drug administration; GAC: Gastric adenocarcinoma (GAC); GEP: Gastroenteropancreatic; GSK3: Glycogen synthetase kinase 3; HGC: Human gastric cancer; HGOs: Human gastric organoids; IL6: Interferon 6; iPCCs: Induced pluripotent cancer cells; iPCSCs: Induced pluripotent cancer stem cells; iPSCs: Induced pluripotent stem cells; KRAS: Kirsten rat sarcoma viral oncogene homolog; MSCs: Mesenchymal stem cells; NEN: Neuroendocrine neoplasm; PCG: Polycomb repressive group; PSCs: Pluripotent stem cells; PTEN: Phosphatase and tensin homolog protein; RA: Retinoic acid; Shh: Sonic hedgehog; TGF $\beta$ : Transforming growth factor- $\beta$; TGFBR2: TGF $\beta$-receptor 2; TrxG: Trithorax group.
\end{abstract}

\section{Acknowledgements}

We thank T. Sato and K. Nanki to teach the cultivation of HGOs.

\section{Authors' contributions}

KW, SS and KKY are the principal authors and were responsible for the first draft of the manuscript. CCK, KK and DCW were responsible for the concept of the review. KM, SS and KKY were responsible for revising the article. All authors read and approved the final manuscripts.

\section{Funding}

This work was supported by grants from the Ministry of Science and Technology (MOST 109-2314-B-037-119; MOST 109-2320-B-037-033), the National Health Research Institutes (NHRI-EX109-10720SI), Kaohsiung Medical University Hospital (SA10803C), and Kaohsiung Medical University (KMU-M106001; KMU-TC108A02).

Availability of data and materials

Please contact author for data requests.

\section{Declarations}

\section{Consent for publication}

Not applicable.

\section{Declaration of use of any animal and human data or tissues}

This study was approved by Kaohsiung Medical University Hospital Ethical Committee (Approval numbers: E(I)-20170111 and E(II)-20170104). We used the human HCM-BROD-0208-C16 cancer model, and primary adenocarcinoma of stomach was purchased from American Type Culture Collection (PDM-146 $6^{\mathrm{TM}}$; ATCC, VA, USA). No direct interaction with the study participants occurred, and no written informed consent for the use of the diagnostic sample for research was needed.

\section{Competing interests}

The authors declare that they have no competing interests.

\section{Author details}

${ }^{1}$ Graduate Institute of Medicine, Kaohsiung Medical University, Kaohsiung 80708, Taiwan. ${ }^{2}$ Regenerative Medicine and Cell Therapy Research Center, Kaohsiung Medical University, Kaohsiung 80708, Taiwan. ${ }^{3}$ Cell Therapy and Research Center, Kaohsiung Medical University Hospital, Kaohsiung 80756, Taiwan. ${ }^{4}$ Department of Infection Biology, Graduate School of Comprehensive Human Sciences, The University of Tsukuba, Tsukuba 305-8577, Japan. ${ }^{5}$ Department of Gastroenterology, Department of Internal Medicines, Kaohsiung Medical University Hospital, Kaohsiung 80756, Taiwan. ${ }^{6}$ Waseda Research Institute of Science and Engineering, Waseda University, Tokyo 169-0051, Japan. ${ }^{7}$ Saito Laboratory of Cell Technology, Yaita, Tochigi 329-1571, Japan.

Received: 11 March 2021 Accepted: 18 July 2021

Published online: 06 September 2021

\section{References}

1. Alzeeb G, Metges JP, Corcos L, Le Jossic-Corcos C. Three-dimensional culture systems in gastric cancer research. Cancers. 2020;12:2800.

2. Kim TH, Shivdasani RA. Stomach development, stem cells and disease. Development. 2016;143:554-65.

3. Xiao S, Zhou L. Gastric stem cells: physiological and pathological perspectives. Front Cell Develop Biol. 2020;8:571536.

4. Han S, Fink J, Jorg DJ, Lee E, Yum MK, Chatzeli L, et al. Defining the identity and dynamics of adult gastric isthmus stem cells. Cell Stem Cell. 2019;25:342-56.

5. Broda TR, McCracken KW, Wells JM. Generation of human antral and fundic gastric organoids from pluripotent stem cells. Nat Protoc. 2019;14:28-50.

6. McCracken KW, Cata EM, Crawford CM, Sinagoga KL, Schumacher M, Rockich BE, et al. Modelling human development and disease in pluripotent stem-cell-derived gastric organoids. Nature. 2014;516:400-4.

7. Hepburn AC, Steele RE, Veeratterapillay R, Wilson L, Kounatidou EE, Barnard A, et al. The induction of core pluripotency master regulators in cancers defines poor clinical outcomes and treatment resistance. Oncogene. 2019;38:4412-24.

8. Saito S, Lin YC, Nakamura Y, Eckner R, Wuputra K, Kuo KK, et al. Potential application of cell reprogramming techniques for cancer research. Cell Mol Life Sci (CMLS). 2019;76:45-65.

9. Wuputra K, Ku CC, Wu DC, Lin YC, Saito S, Yokoyama KK. Prevention of tumor risk associated with the reprogramming of human pluripotent stem cells. J Exp Clin Cancer Res (CR). 2020;39:100.

10. Huang C, Hu CG, Ning ZK, Huang J, Zhu ZM. Identification of key genes controlling cancer stem cell characteristics in gastric cancer. World J Gastrointest Surg. 2020;12:442-59.

11. Li L, Zhu Z, Zhao Y, Zhang Q, Wu X, Miao B, et al. FN1, SPARC, and SERPINE1 are highly expressed and significantly related to a poor prognosis of gastric adenocarcinoma revealed by microarray and bioinformatics. Sci Rep. 2019;9:7827.

12. Ramezankhani R, Solhi R, Es HA, Vosough M, Hassan M. Novel molecular targets in gastric adenocarcinoma. Pharmacol Therap. 2021;220:107714. 
13. Jones PA, Issa JP, Baylin S. Targeting the cancer epigenome for therapy. Nat Rev Genet. 2016;17:630-41.

14. Torres CM, Biran A, Burney MJ, Patel H, Henser-Brownhill T, Cohen AS, et al. The linker histone $\mathrm{H} 1.0$ generates epigenetic and functional intratumor heterogeneity. Science. 2016;353:1644.

15. Mathur R, Alver BH, San Roman AK, Wilson BG, Wang X, Agoston AT, et al. ARID1A loss impairs enhancer-mediated gene regulation and drives colon cancer in mice. Nat Genet. 2017;49:296-302.

16. Nebbioso A, Tambaro FP, Dell'Aversana C, Altucci L. Cancer epigenetics: Moving forward. PLoS Genet. 2018;14:e1007362.

17. Liao J, Marumoto T, Yamaguchi S, Okano S, Takeda N, Sakamoto C, et al. Inhibition of PTEN tumor suppressor promotes the generation of induced pluripotent stem cells. Mol Therapy: J Am Soc Gene Therapy. 2013;21:1242-50.

18. Chen CL, Wang LJ, Yan YT, Hsu HW, Su HL, Chang FP, et al. Cyclin D1 acts as a barrier to pluripotent reprogramming by promoting neural progenitor fate commitment. FEBS Lett. 2014;588:4008-17.

19. Gustafson WC, Weiss WA. Myc proteins as therapeutic targets. Oncogene. 2010;29:1249-59.

20. Wei D, Kanai M, Huang S, Xie K. Emerging role of KLF4 in human gastrointestinal cancer. Carcinogenesis. 2006;27:23-31.

21. Chiou SH, Wang ML, Chou YT, Chen CJ, Hong CF, Hsieh WJ, et al. Coexpression of Oct4 and Nanog enhances malignancy in lung adenocarcinoma by inducing cancer stem cell-like properties and epithelial-mesenchymal transdifferentiation. Can Res. 2010;70:10433-44.

22. Ji W, Jiang Z. Effect of shRNA-mediated inhibition of Nanog gene expression on the behavior of human gastric cancer cells. Oncol Lett. 2013;6:367-74.

23. Lin YC, Murayama Y, Hashimoto K, Nakamura Y, Lin CS, Yokoyama KK, et al. Role of tumor suppressor genes in the cancer-associated reprogramming of human induced pluripotent stem cells. Stem Cell Res Ther. 2014;5:58.

24. Al-Hajj M, Wicha MS, Benito-Hernandez A, Morrison SJ, Clarke MF. Prospective identification of tumorigenic breast cancer cells. Proc Natl Acad Sci USA. 2003;100:3983-8

25. Singh SK, Clarke ID, Terasaki M, Bonn VE, Hawkins C, Squire J, et al. Identification of a cancer stem cell in human brain tumors. Can Res. 2003;63:5821-8.

26. Bonnet D, Dick JE. Human acute myeloid leukemia is organized as a hierarchy that originates from a primitive hematopoietic cell. Nat Med. 1997;3:730-7

27. Zhang C, Li C, He F, Cai Y, Yang H. Identification of CD44+CD24+ gastric cancer stem cells. J Cancer Res Clin Oncol. 2011;137:1679-86.

28. Ren F, Sheng WQ, Du X. CD133: a cancer stem cells marker, is used in colorectal cancers. World J Gastroenterol. 2013:19:2603-11.

29. Schwitalla S, Fingerle AA, Cammareri P, Nebelsiek T, Goktuna SI, Ziegler PK, et al. Intestinal tumorigenesis initiated by dedifferentiation and acquisition of stem-cell-like properties. Cell. 2013;152:25-38.

30. Gong X, Azhdarinia A, Ghosh SC, Xiong W, An Z, Liu Q, et al. LGR5-Targeted Antibody-Drug Conjugate Eradicates Gastrointestinal Tumors and Prevents Recurrence. Mol Cancer Ther. 2016;15:1580-90.

31. Song $Y$, Wang $Y$, Tong $C, X i H$, Zhao $X$, Wang $Y$, et al. A unified model of the hierarchical and stochastic theories of gastric cancer. Br J Cancer. 2017;116:973-89.

32. Kumano K, Arai S, Hosoi M, Taoka K, Takayama N, Otsu M, et al. Generation of induced pluripotent stem cells from primary chronic myelogenous leukemia patient samples. Blood. 2012;119:6234-42.

33. Miyoshi N, Ishii H, Nagai K, Hoshino H, Mimori K, Tanaka F, et al. Defined factors induce reprogramming of gastrointestinal cancer cells. Proc Natl Acad Sci USA. 2010;107:40-5.

34. Noguchi K, Eguchi H, Konno M, Kawamoto K, Nishida N, Koseki J, et al. Susceptibility of pancreatic cancer stem cells to reprogramming. Cancer Sci. 2015;106:1182-7.

35. Wu DC, Wang SSW, Liu CJ, Wuputra K, Kato K, Lee YL, et al. Reprogramming antagonizes the oncogenicity of HOXA13-long noncoding RNA HOTTIP axis in gastric cancer cells. Stem cells. 2017;35:2115-28.

36. Chiou SS, Wang SS, Wu DC, Lin YC, Kao LP, Kuo KK, et al. Control of oxidative stress and generation of induced pluripotent stem cell-like cells by Jun dimerization protein 2. Cancers. 2013:5:959-84.

37. Barker N, Huch M, Kujala P, van de Wetering M, Snippert HJ, van Es JH, et al. Lgr5(+ve) stem cells drive self-renewal in the stomach and build long-lived gastric units in vitro. Cell Stem Cell. 2010;6:25-36.
38. Stange DE, Koo BK, Huch M, Sibbel G, Basak O, Lyubimova A, et al. Differentiated Troy+ chief cells act as reserve stem cells to generate all lineages of the stomach epithelium. Cell. 2013;155:357-68.

39. Gifford GB, Demitrack ES, Keeley TM, Tam A, La Cunza N, Dedhia PH, et al. Notch1 and Notch2 receptors regulate mouse and human gastric antral epithelial cell homoeostasis. Gut. 2017;66:1001-11.

40. Sato $T$, Stange DE, Ferrante $M$, Vries RG, Van Es JH, Van den Brink S, et al. Long-term expansion of epithelial organoids from human colon, adenoma, adenocarcinoma, and Barrett's epithelium. Gastroenterology. 2011;141:1762-72.

41. McCracken KW, Aihara E, Martin B, Crawford CM, Broda T, Treguier J, et al. Wnt/beta-catenin promotes gastric fundus specification in mice and humans. Nature. 2017;541:182-7.

42. Noguchi TK, Ninomiya N, Sekine M, Komazaki S, Wang PC, Asashima M, et al. Generation of stomach tissue from mouse embryonic stem cells. Nat Cell Biol. 2015;17:984-93.

43. Schumacher MA, Aihara E, Feng R, Engevik A, Shroyer NF, Ottemann KM, et al. The use of murine-derived fundic organoids in studies of gastric physiology. J Physiol. 2015;593:1809-27.

44. Pompaiah M, Bartfeld S. Gastric organoids: an emerging model system to study Helicobacter pylori pathogenesis. Curr Top Microbiol Immunol. 2017:400:149-68.

45. Fujii M, Clevers H, Sato T. Modeling human digestive diseases with CRISPR-Cas9-modified organoids. Gastroenterology. 2019;156:562-76.

46. Artegiani B, Hendriks D, Beumer J, Kok R, Zheng X, Joore I, et al. Fast and efficient generation of knock-in human organoids using homologyindependent CRISPR-Cas9 precision genome editing. Nat Cell Biol. 2020;22:321-31.

47. Seidlitz T, Merker SR, Rothe A, Zakrzewski F, von Neubeck C, Grutzmann K, et al. Human gastric cancer modelling using organoids. Gut. 2019:68:207-17.

48. Vlachogiannis G, Hedayat S, Vatsiou A, Jamin Y, Fernandez-Mateos J, Khan $\mathrm{K}$, et al. Patient-derived organoids model treatment response of metastatic gastrointestinal cancers. Science. 2018;359:920-6.

49. Nanki K, Toshimitsu K, Takano A, Fujii M, Shimokawa M, Ohta Y, et al. Divergent routes toward Wnt and R-spondin niche independency during human gastric carcinogenesis. Cell. 2018;174:856-69.

50. Yan HHN, Siu HC, Law S, Ho SL, Yue SSK, Tsui WY, et al. A comprehensive human gastric cancer organoid biobank captures tumor subtype heterogeneity and enables therapeutic screening. Cell Stem Cell. 2018;23:882-97.

51. Ukai S, Honma R, Sakamoto N, Yamamoto Y, Pham QT, Harada K, et al. Molecular biological analysis of 5-FU-resistant gastric cancer organoids; KHDRBS3 contributes to the attainment of features of cancer stem cell. Oncogene. 2020;39:7265-78.

52. Lauren P. The two histological main types of gastric carcinoma: diffuse and so-called intestinal-type carcinoma. an attempt at a histo-clinical classification. Acta Pathol Microbiol Scand. 1965;64:31-49.

53. Koo BK, Spit M, Jordens I, Low TY, Stange DE, van de Wetering M, et al. Tumour suppressor RNF43 is a stem-cell E3 ligase that induces endocytosis of Wnt receptors. Nature. 2012;488:665-9.

54. Proffitt KD, Madan B, Ke Z, Pendharkar V, Ding L, Lee MA, et al. Pharmacological inhibition of the Wnt acyltransferase PORCN prevents growth of WNT-driven mammary cancer. Can Res. 2013;73:502-7.

55. Wang Z, Dolle P, Cardoso WV, Niederreither K. Retinoic acid regulates morphogenesis and patterning of posterior foregut derivatives. Dev Biol. 2006:297:433-45.

56. Workman MJ, Mahe MM, Trisno S, Poling HM, Watson CL, Sundaram N, et al. Engineered human pluripotent-stem-cell-derived intestinal tissues with a functional enteric nervous system. Nat Med. 2017;23:49-59.

57. Munera JO, Wells JM. Generation of gastrointestinal organoids from human pluripotent stem cells. Methods Mol Biol. 2017;1597:167-77.

58. Salama NR, Hartung ML, Muller A. Life in the human stomach: persistence strategies of the bacterial pathogen Helicobacter pylori. Nat Rev Microbiol. 2013;11:385-99.

59. Yao X, Smolka AJ. Gastric parietal cell physiology and helicobacter pyloriinduced disease. Gastroenterology. 2019;156:2158-73.

60. O'Rourke JL, Lee A. Animal models of Helicobacter pylori infection and disease. Microbes Infect. 2003;5:741-8. 
61. Finkbeiner SR, Zeng XL, Utama B, Atmar RL, Shroyer NF, Estes MK. Stem cell-derived human intestinal organoids as an infection model for rotaviruses. MBio. 2012;3:e00159-12.

62. Forbester JL, Goulding D, Vallier L, Hannan N, Hale C, Pickard D, et al. Interaction of Salmonella enterica Serovar Typhimurium with intestinal organoids derived from human induced pluripotent stem cells. Infect Immun. 2015:83:2926-34.

63. Leslie JL, Huang S, Opp JS, Nagy MS, Kobayashi M, Young VB, et al. Persistence and toxin production by Clostridium difficile within human intestinal organoids result in disruption of epithelial paracellular barrier function. Infect Immun. 2015;83:138-45.

64. Carr DF, Ayehunie S, Davies A, Duckworth CA, French S, Hall N, et al. Towards better models and mechanistic biomarkers for drug-induced gastrointestinal injury. Pharmacol Ther. 2017;172:181-94.

65. Gjorevski N, Sachs N, Manfrin A, Giger S, Bragina ME, Ordonez-Moran $P$, et al. Designer matrices for intestinal stem cell and organoid culture. Nature. 2016;539:560-4

66. Candiello J, Grandhi TSP, Goh SK, Vaidya V, Lemmon-Kishi M, Eliato KR, et al. 3D heterogeneous islet organoid generation from human embryonic stem cells using a novel engineered hydrogel platform. Biomaterials. 2018;177:27-39.
67. Koike H, Iwasawa K, Ouchi R, Maezawa M, Giesbrecht K, Saiki N, et al. Modelling human hepato-biliary-pancreatic organogenesis from the foregut-midgut boundary. Nature. 2019;574:112-6.

68. Bar-Ephraim YE, Kretzschmar K, Clevers H. Organoids in immunological research. Nat Rev Immunol. 2020;20:279-93.

69. Yuki K, Cheng N, Nakano M, Kuo CJ. Organoid Models of Tumor Immunology. Trends Immunol. 2020:41:652-64.

70. Kayisoglu Ö, Schlegel N, Bartfeld S. Gastrointestinal epithelial innate immunity-regionalization and organoids as new model. J Mol Med. 2021;99:517-30.

71. Kawasaki K, Toshimitsu K, Matano M, Fujita M, Fujii M, Togasaki K, et al. An organoid biobank of neuroendocrine neoplasms enables genotypephenotype mapping. Cell. 2020;183:1420-35.

\section{Publisher's Note}

Springer Nature remains neutral with regard to jurisdictional claims in published maps and institutional affiliations.
Ready to submit your research? Choose BMC and benefit from:

- fast, convenient online submission

- thorough peer review by experienced researchers in your field

- rapid publication on acceptance

- support for research data, including large and complex data types

- gold Open Access which fosters wider collaboration and increased citations

- maximum visibility for your research: over $100 \mathrm{M}$ website views per year

At BMC, research is always in progress.

Learn more biomedcentral.com/submissions 